\title{
Application of Remote Sensing Techniques for Mapping Shifting Cultivation
}

\author{
N.Vijaya Kumari \\ VNR Vignana Jyothi Institute of Engineering and Technology Hyderabad - 500090
}

\begin{abstract}
Shifting cultivation is an ancient and primitive method of cultivation, also referred to as 'slash and burn' or 'rotational bush fallow agricultural system'. The practice mainly involves removal of the forests by primitive slash and burn technique followed by mixed cropping for short period before abandoning the site. Tribals all over India are known to follow the practice of shifting cultivation with some regional variations. The present study has been undertaken to estimate the spatial distribution of podu cultivation in Srikakulam district of Andhra Pradesh by using remote sensing techniques. Results of the present study indicate that an estimated area of 10,491.857 acres of the forest area is under shifting cultivation in Srikaku lam district. Shifting cultivation has caused a great deal of environmental degradation. Remote sensing techniques with repetitive coverage and synoptic view provide database for assessing environment degrading practices. Mapping of shifting areas is important not only from ecological point of $v$ iew but also for management purposes.

Keywords: Shifting cultivation, re mote sensing, mapping, environ ment,
\end{abstract}

\section{INTRODUCTION}

Shifting cultivation is a traditional form of agriculture practiced mostly by tribals in the hilly tracts of the region. This agricultural system is termed 'Shifting cultivation' indicating movement from one plot to another or 'Slash and burn' referring to the means of destroying the forest lands. It is also known as 'Rotational bush fallow agriculture' as the system functions in a cyclic manner. Shifting cultivation mainly involves selection and removal of forests by slash and burn techniques followed by mixed cropping, harvesting and fallowing for a short period before abandoning the site(Fig.1)

The rationale of shifting cultivation is simple (Plate -1). The orig inal forests and the fallowed areas in which trees and other plant species grow provide several benefits (Nair, 1990). During the fallow period trees replenish the soil organic matter, thereby improving soil structure and prevents soil erosion and excessive water runoff (Plate-1). Thus, ideally slash and burn cultivation is ecologically stable under very low density of human population and was operated successfully for subsistence. However, in recent times increased population density led to intensive shifting cultivation with shorter fallows resulting in poor yields and decline in soil fertility (Sharma, 1976).

Shifting cultivation is practiced with some variations throughout the tropical and subtropical regions of the world. Reports indicate that nearly about 36 million sq.km. of global area is under slash and burn cultivation and is a means of livelihood for 10 per cent of the world's population (Hauck,1973). Shifting cultivation is widespread in the Amazon basin, South west china, Africa, Korea, Vietnam and neighboring counties and is known by various names. Reports indicate Africa as having the largest area under shifting cultivation followed by Latin A merica (Conklin, 1957).

India is the only country where shifting cultivation is confined to hill areas in the Northeast, Southern Orissa and tribal belts of Andhra Pradesh and is commonly known by the local vernacular names. The problem of shifting cultivation is acute in Andhra Pradesh, Orissa and North-eastern states whereas it is limited in Madhya Pradesh and Bihar. As per the task force of Ministry of Agriculture nearly 9.95 million hectares of land in India is under shifting cultivation. However, because of its transient nature the exact total area requires periodic monitoring. According to Planning Commission (1982) 233 blocks spread over 62 districts in 16 states the jhum is practiced involving 12 per cent of tribal population.

Study area

In Andhra Pradesh shifting cultivation is extensively practiced in the districts of Srikakulam, Vizianagaram, Visakhapatnam, Khammam and East and West Godavari and sparsely in Adilabad district. Shifting cultivation is known as 'Podu' in the local vernacular in Srikakulam district and in coastal areas. The present project was undertaken to estimate the areal extent of shifting cultivation in Srikakulam district of Andhra Pradesh, by using remote sensing techniques. 
The study area namely Srikaku lam district is part of eastern ghats of Andhra Pradesh. The total area of Srikaku lam district is 5,837 sq.km. and is situated within the geographic co-ordinates of 18-21' and 19-10' of northern latitude and 83-5' and $84-51$ ' of eastern longitude (Fig.2 - location map). The district is divided into two natural regions namely the hilly region called the agency area in the north-western parts of the district and the plains. The hilly region occupies about $1 / 3^{\text {rd }}$ of the total area of the district and is mostly under 'Podu' cultivation. According to Roy (1990) shifting cultivation is practiced in the hilly terrain where gentle slope of land, high rainfall, moderate temperature and good soil favor quick growth of plants.

\section{METHODOLOGY}

The delineation and mapping of podu areas under shifting cultivation was done by visual interpretation technique using IRS-IB LSS II FCC print of path 21 and row 55 covering the study area (Fig. 3). Areas under podu cultivation were delineated on an overlay and finally transferred onto the topographical base map prepared at 1:50,000scale (Plate - 2). The final map area was calculated using the grid sheet method.

\section{RESULTS AND DISCUSSION}

The total geographical area of Srikaku lam district is 498512 acres with an estimated forest area of 133691 acres. In the present study results indicate that podu is practiced in 10491.57 acres of the forest area (Fig.-4). This constitutes about 7.84 per cent of the total forest area encroached upon by the tribal population. Shifting cultivation with a short fallow period causes loss of soil fertility and promotes growth of exotic weeds and prevents natural regeneration of the forest. Ultimately, the podu fields are simply abandoned when they are uneconomical and then new forest regions will be encroached.

The main reason for podu cultivation are insufficient extent of valley land, less crop produce and need to meet food requirement. This was revealed by the study conducted by Admin is trative Staff College of India (1986) Hyderabad. This was also supported by baseline survey conducted in the districts covered by Andhra Pradesh Development Project (1989).

Srikakulam district comprises of 1.34 lakh tribal population and the predominant tribal groups practicing shifting cultivation in this region are known as Savara, Jatapu, Gadaba and Konda Dora. Podu cultivators are highly skilled at adapting their cropping practices to the environment in which they are working. Estimates reveal that an area of $10,491.875$ acres of the forest area is under shifting cultivation in Srikaku lam district. Nearly 18.51 per cent of the tribal population are engaged in the practice of podu which is the main source of livelihood.

\section{Ecological Implications}

The ecological implications of shifting cultivation are disastrous. It is one of the main reasons for deforestation and soil degradation. Natural regeneration of vegetation is inhibited due to the shorter fallow periods causing irreparable damage to the forest ecosystem. In the past the fallow periods were long about 20-30 years and has been considerably reduced to 5 years. As indicated in Govern ment of India Task force (1983) report on shifting cultivation, the fallow period in Andhra Pradesh is 3 years which was the lowest in the entire country. It has been estimated (EPA, 1990) that about 25 per cent of global warming is attributable to the burning of forests.

The resultant ecological imbalance will definitely have a significant negative impact on the socio-economic conditions of the tribals. It is apparent that this traditional system of cultivation is unsatisfactory under such conditions and has to be replaced by a more permanent and productive system in order to save the region from an ecological crisis, which if left unchecked will endanger the very existence of the tribal community.

\section{CONCLUSIONS}

Shifting cultivation also known as slash and burn is a traditional form of agriculture practiced mostly by the tribal people living in the hilly tracts of the forest region. Podu cultivation is of widespread occurrence in the forest zone of Srikakulam district. The ecological implications of podu cultivation are disastrous causing deforestation and degradation. The present study demonstrated that IRS data can be successfully utilized for mapping and monitoring areas under shifting cultivation. Remote sensing is a most useful tool to monitor natural resources and related environmental problems leading to suitable management strategies which would enrich the socio-economic conditions of the tribals and also for sustainable development in future.

\section{REFERENCES}

[1]. Nair, P.R., Prospects for agro-forestry in the tropics., World technical paper., Washington D.C.1990, 113.

[2]. Sharma, T.G., Shifting cultivation in north eastern India., NEI Council for Scientific Research, Shillong, 1976, 1-3. 
[3]. Hauck, F.W., Shifting cultivation and soil conservation in Africa., FAO soils bull. 1973, 24, 1-4.

[4]. Conklin,H.C., Hanunoo agriculture, F.A.O. Forestry development, F.A.O. Rome 109.1957, paper no. 12.
[5]. Roy Burman, B.K., Anoverview of shifting cultivation in India. In: Shifting cultivation in north -eastern India. D.N., Ed. Omsons publications, New Delhi., 1990, 1-13.

[6]. Environment Protection Act., US-EPA; WSH.DC. Greenhouse gas emissions from agricultural systems., 1990, vols. 1-2.

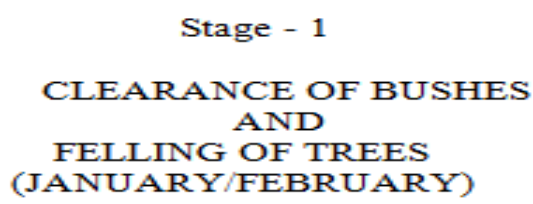

Stage -6

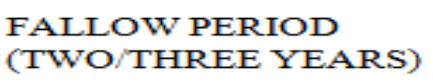

PODU CYCLE

$$
\text { Stage }-5
$$

\section{HARVESTING} (OCTOBER/DECEMBER)

\author{
Stage - 2 \\ BURNING AND \\ ASH SPREAD ON FIELD \\ (MARCH/MAY)
}

Stage -3

DIBBLING OF SOIL AND SEED BROADCAST (JUNE/JULY)

Stage - 4

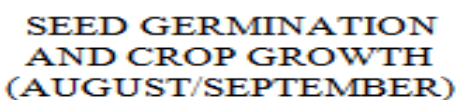

Figure - 2 Location map

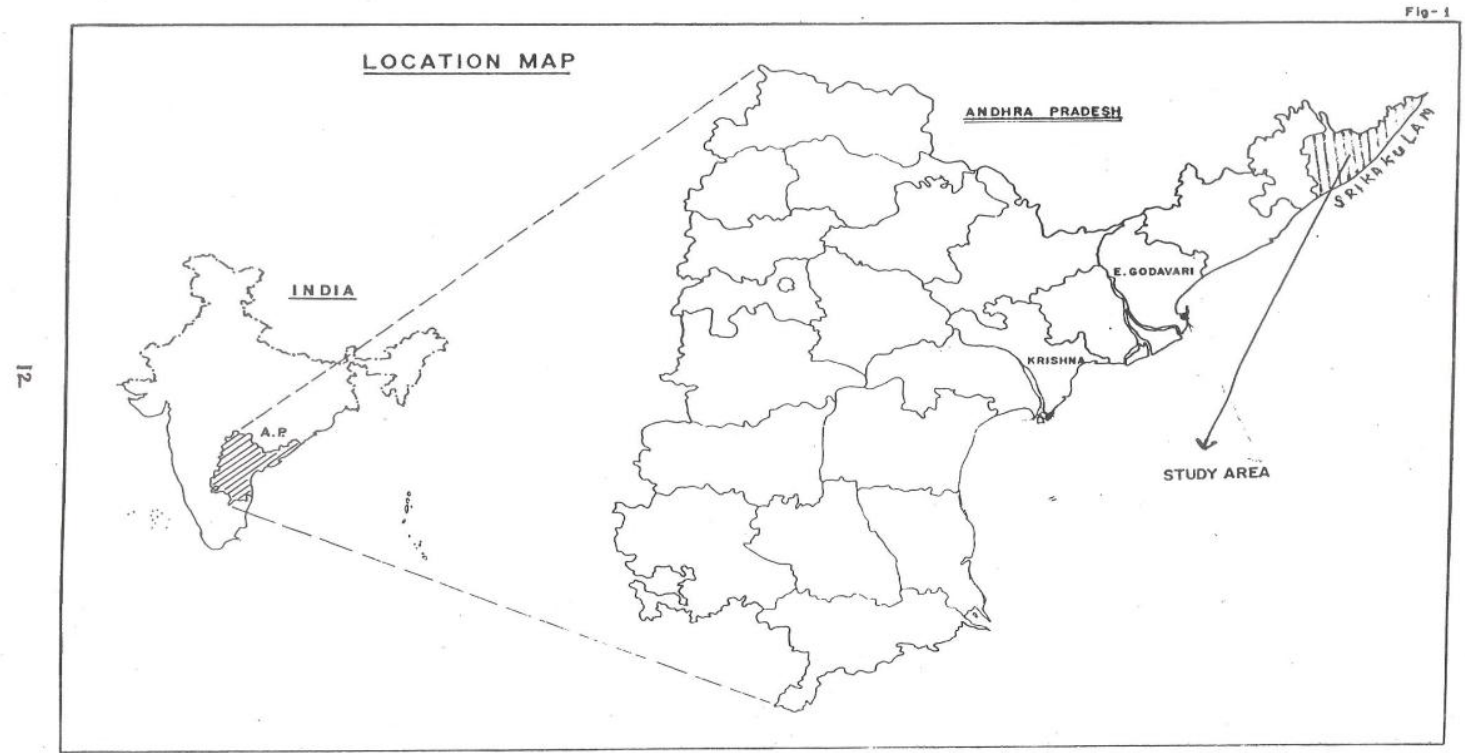

Fig. 3 - Schematic representation of Visual Interpretation 
STEP 1: ANALOG DATA

STEP 2: PRELIMINARY INTERPRETATION

STEP 3: DELINEATION ON IMAGE OF 1:50000 SCALE

STEP 4: FINALISATION OF INTERPRETATION.

STEP 5: TRANSFER OF THEMATIC DETAILS

STEP 6: MAP FINALIZATION

STEP 7: AREA CALCULATION.

Plate -1

\section{SHIFTING CULTIVATION CONCEPTUAL MODEL}

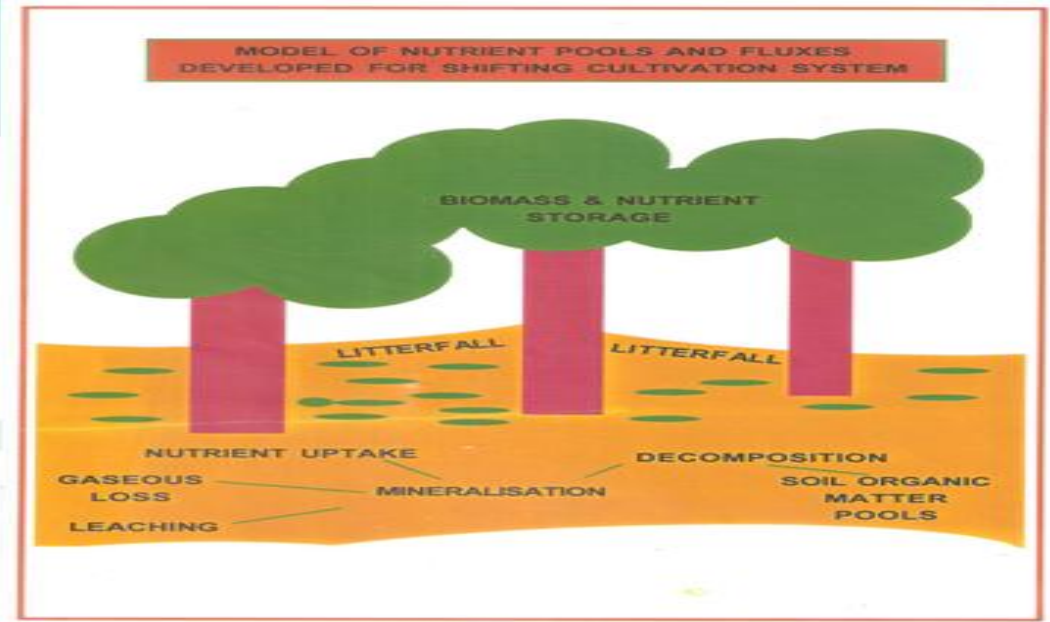

Plate - 2

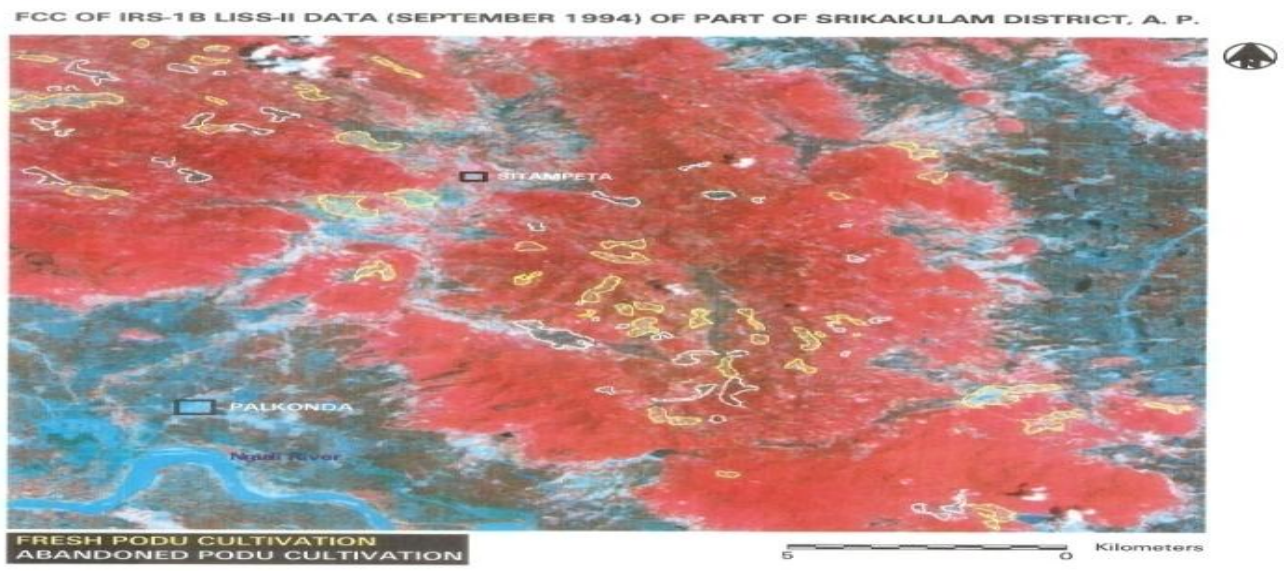

Figure 4: 


\section{FIGURE}

HISTOGRAM REPRESENTING THE TOTAL AREA UNDER PODU CULTIVATION IN SRIKAKULAM DISTRICT

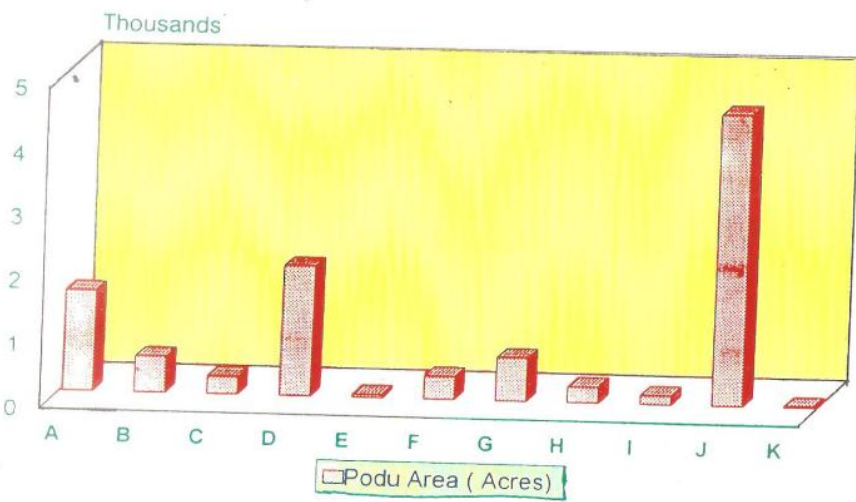

$$
\begin{aligned}
& \text { Bhamini } \\
& \text { Hiramandalam } \\
& \text { Kotturu } \\
& \text { Meliaputti. } \\
& \text { Nandigam } \\
& \text { Palakonda } \\
& \text { Patapatnam } \\
& \text { Sarbujili } \\
& \text { Sarvakota } \\
& \text { Seethampeta } \\
& \text { Tekkali }
\end{aligned}
$$

